Epidemiologic Response to an Earthquake Emergency, Turkey, August 1999: Perspectives from a Foreign Health Team

Josepbine Malilay, PhD, MPH; ${ }^{1}$ Dabna Batts-Osbome, MD, FACEP, ${ }^{1}$ Thomas Dolan ${ }^{2}$

1) Disaster Assessment and Epidemiology, Health Studies Branch, Division of Environmental Hazards and Health Effects, National Center for Environmental Health, Centers for Disease Control and Prevention, Atlanta, Georgia USA; 2) Office of Foreign Disaster Assistance, Agency for International Development, State Department, Washington, DC, USA

Objective: To demonstrate how epidemiological methods can guide foreign emergency responses following a major earthquake in western Turkey.

Methods: To assess the needs and health status of affected communities, we interviewed 45 households selected by convenience from 3 sites for: 1) demographic information; 2) morbidity; 3) medical attention; 4) mortality; and 5) needs for shelter, water, and sanitation. We conducted face-to-face interviews with authorities about a reported case of typhoid. To evaluate hospital needs, we surveyed hospitals in the earthquake zone and in Istanbul.

Results: Study households, representing 150 families and 728 persons, consisted on average of 3.3 families (mean family size: 4.6 people). Eighty-seven percent reported having a member age of $\geq 50$ years. Although $67 \%$ had damaged but habitable structures, they remained in outdoor tents while awaiting structural inspections. Seven (16\%) reported a death; $14(31 \%)$ reported at least one injured member; and 17 (3.8\%) reported at least one ill member. Medical attention was available. Almost $60 \%$ of hospitals reported needing temporary facilities, medical equipment, and instruments to replace pre-quake losses. The case of typhoid was unsubstantiated.

Conclusions: Application of epidemiological methods demonstrated that: 1) households required evaluation of building safety; shelter and sanitation; mental health counseling; education about disease transmission; and enhanced disease surveillance among the elderly, and 2) hospitals required prefabricated buildings, selected equipment, and instruments. The information provided a basis for directing appropriate responses by the United States government.

Keywords: earthquake; epidemiology; epidemiological response; hospitals; public health response; rapid needs assessment Email: jym7@cdc.gov

\section{Mobile Ukrainian Hospital in the Earthquake in Turkey}

G.G. Roshchyn; S.E. Guriev; V.N. Padalka; Pb.N. Novikov; Prof.. I.P. Shlapak; Y.O. Polentsov

Kiev Medical Academy of Postgraduate Training, Ukrainian Center of Emergency and Disaster Medicine, Kiev, UKRAINE

Introduction: The Ukrainian Mobile Hospital of the Ministry for Extreme Situations arrived in Turkey on the 6th day after the earthquake, which happened on 17 August 1999, and worked there for 20 days. The Hospital was located $10 \mathrm{~km}$ from epicenter of the earthquake. Within 15 minutes after arrival, the first patient was admitted to our hospital.

Material and Methods: During this 20 day period, 5,432 patients were admitted to the mobile hospital (Table 1); one-third were children. Since the hospital began providing care on the 4th day after the earthquake, not too many of the patients were victims of acute trauma. Patients with infectious diseases appeared to comprise the most frequently admitted group. Also, one-third of all patients required treatment by surgeons and/or orthopedic surgery: 35 of them were operated successfully. All patients received conventional therapy.

Table 1-Characteristics of patients

$\begin{array}{lrr}\text { Patients } & \text { Number } & (\%) \\ \text { Children } & 1,847 & (34.0) \\ \text { Surgery } & 35 & (0.6) \\ \text { ICU } & 117 & (2.3) \\ \text { Deceased } & 0 & (0.0) \\ \text { Total } & 5,432 & (100.0)\end{array}$

Table 2-Distribution of patients by groups

$\begin{array}{lcr}\text { Group } & \text { Amount } & (\%) \\ \text { Surgical } & 1,495 & (27.5) \\ \text { Orthopedic } & 429 & (7.9) \\ \text { Medical } & 984 & (18.1) \\ \text { Infectious } & 2,188 & (40.3) \\ \text { Other } & 336 & (6.2) \\ \text { Total } & 5,432 & (100.0)\end{array}$

Results: The main result was $0 \%$ mortality rate despite the fundamental change of pathologies within a 20 day period of work. Trauma and its consequences that prevailed during the first days of the disaster, were slowly "replaced" within two weeks with infectious diseases and medical problems. Such changes demanded well-organized team cooperation as well as trained and experienced staff with rather vast knowledge.

Conclusion: Experience obtained from the participation in this disaster led us to the conclusion of the necessity of having special programs, both for individual preparation and for team training. It should include the staff going to work in a mobile hospital. Such a program is under creation.

Keywords: disaster; earthquake; hospital, mobile; infectious disease; pathology; team; trauma; Turkey; Ukraine

E-mail: polentsov@doctor.com 